\title{
ARTE E MEIO AMBIENTE: OS RECURSOS HÍDRICOS BRASILEIROS PELA PERSPECTIVA NAIF
}

\section{ARTIGO ORIGINAL}

OLIVEIRA, Hebe Souza de ${ }^{1}$

WACHHOLZ, Flávio ${ }^{2}$

OLIVEIRA, Hebe Souza de. WACHHOLZ, Flávio. Arte e Meio Ambiente: Os recursos hídricos brasileiros pela perspectiva NAIF. Revista Científica Multidisciplinar Núcleo do Conhecimento. Ano 05, Ed. 06, Vol. 12, pp. 37-60. Junho de 2020. ISSN: 2448-0959, Link de acesso: https://www.nucleodoconhecimento.com.br/arte/arte-e-meio-ambiente

\section{RESUMO}

O Brasil é um país privilegiado no que diz respeito à quantidade de água disponível em seu território. A forma como a água é representada nas pinturas evidencia a percepção do artista sobre esse recurso natural. O objetivo deste trabalho foi ressaltar a importância dos recursos hídricos brasileiros e divulgar a arte naif. No que tange aos procedimentos metodológicos, foi realizada uma pesquisa documental, baseada nos catálogos das exposições: Bienal Naifs do Brasil do SESC de Piracicaba/SP (1996 a

${ }_{1}^{1}$ Mestranda em Gestão e Regulação de Recursos Hídricos pela Universidade do Estado do Amazonas (UEA); Pós-graduada em Administração, Finanças Empresariais e Negócios pela Escola Superior Aberta do Brasil (ESAB); Pós-graduada em Ensino de Arte e História pela Faculdade Cidade Verde; Formada em Licenciatura em Artes Visuais pela Universidade Federal do Amazonas (UFAM); Bacharel em Ciências Contábeis pelo Centro Universitário de Ensino Superior do Amazonas (CIESA).

2 Pós-Doutorado pela Universidade Federal de Goiás (UFG); Doutorado em Geografia pela Universidade Estadual Paulista Júlio de Mesquita Filho (UNESP); Graduação em Geografia pela Universidade Federal de Santa Maria (UFSM). 
2018); Bienal Internacional de Arte Naif Totem Cor-Ação - BINAIF de Socorro/SP (2017 e 2019); e a Mostra Nacional de Arte Naif no Estado de São Paulo (2019). O estudo foi descritivo, com análise qualitativa das pinturas e as suas relações com os recursos hídricos, por sua vez, os recursos hídricos pintados nas obras foram apresentados de forma técnica. Foram selecionadas 15 obras pela relevância pertinente ao tema. O conjunto das pinturas analisadas contempla os usos múltiplos das águas, além de aspectos geográficos, históricos, culturais e diferentes biomas das bacias hidrográficas. Observou-se ainda, problemas como inundação, escassez e poluição dos recursos hídricos. A pesquisa fez uma viagem pelo Brasil, de norte a sul, tratando tanto das águas continentais quanto das águas oceânicas que banham o litoral do país. Diante disso, conclui-se que a água é um recurso natural indispensável, valorizá-la por meio da arte naif também incentiva a sua preservação e dessa maneira contribui com a gestão dos recursos hídricos.

Palavras-chave: Meio ambiente, recursos hídricos, arte naif.

\section{INTRODUÇÃO}

A água é um recurso natural essencial, ela é sinônimo de vida. O Brasil é um país privilegiado no que diz respeito à quantidade de água disponível em seu território, embora existam locais com abundância e outros com escassez (TUNDISI, 2014). É justamente quando falta água que muitas pessoas percebem que não é possível viver sem água. Logo, a água é indispensável e preciosa. Mas, infelizmente, vem sofrendo

agressões como a poluição e o desperdício (ANA, 2012). É preciso valorizar a água e nesse ponto, a arte pode ser uma importante ferramenta reflexiva. A arte faz parte da cultura da humanidade desde os primórdios tempos das cavernas. A forma como a água é representada nas pinturas evidencia a percepção do artista sobre esse recurso natural. Neste contexto, a arte naif é interessante porque o artista é livre para criar e se expressar, sem precisar se preocupar com padrões estéticos (FINKELSTEIN, 2001). Diante disso, o objetivo deste trabalho foi ressaltar a importância dos recursos hídricos brasileiros e divulgar a arte naif. A pesquisa documental foi baseada nos catálogos de exposições importantes de arte naif realizadas no país nos últimos 23 anos. No que se refere aos procedimentos metodológicos, foram feitas análises 
qualitativas das pinturas, por sua vez, os recursos hídricos pintados nas obras foram apresentados de forma técnica. Portanto, trata-se de uma pesquisa que envolve ciências ambientais e artes.

\subsection{A HISTÓRIA DA ARTE NAIF}

Segundo a Enciclopédia Itaú Cultural (2020), a história da Arte naif está ligada as pinturas de Henri Rousseau, exibidas no Salon des Indépendents (Salão dos Independentes), realizado em 1886, em Paris. A palavra naif vem da língua francesa e significa ingênuo, sendo a expressão usada para designar a arte do pintor. Apesar de no início Rousseau ter sido muito criticado, ele acabou se tornando uma grande influência para pintores das vanguardas da época (FINKELSTEIN, 2001). Henri Rousseau foi o nome de maior destaque na arte naif, mas ele não foi o único representante. Segundo a Enciclopédia Itaú Cultural (2020), a arte naif não foi algo isolado e que ocorreu apenas na França, pelo contrário, muitos outros artistas surgiram em todo mundo, como Alfred Wallis (Inglaterra) e Anna Mary Robertson (Estados Unidos). Não tendo características estéticas típicas, o que torna uma arte naif é o artista, já que é uma arte individual e cada artista tem um estilo único e genuíno. Muitos artistas naifs são autodidatas, mas existem artistas naifs que possuem formação artística (FINKELSTEIN, 2001). Segundo D'Ambrosio (2013), o artista naif não segue modismos, mas desenvolve um estilo pessoal e não uma imitação. Existem museus especializados em arte naif por todo planeta, como na Alemanha, Bélgica, Canadá, Croácia, França, Portugal e Rússia. No Brasil, destacase o Museu do Sol em Penápolis/SP, o Museu de Arte Naif de Guarabira/PB e o Museu Internacional de Arte Naif do Brasil (MIAN), no Rio de Janeiro/RJ, fundado pelo francês radicado Lucien Finkelstein (1931-2008). Além dos museus, existem também galerias especializadas, a exemplo da Galeria de Jacques Ardies, em São Paulo/SP. A arte naif também conta com grandes eventos, como o Art Naif Festiwal (Festival de Arte Naif) que ocorre na Polônia anualmente, com a participação de artistas de vários de países. 


\subsection{A ARTE NAIF NO BRASIL}

No início do século XX existiram muitas vanguardas artísticas, e cada vanguarda tinha características estéticas específicas, como o cubismo, por exemplo. No caso da arte naif é diferente porque não é algo planejado por um grupo de artistas ou intelectuais, não guarda, portanto, características estéticas comuns ou específicas (FINKELSTEIN, 2001). No Brasil, um dos artistas da arte naif de maior destaque internacional foi o acreano Chico da Silva (1910-1985). Ele chegou a receber uma menção honrosa na 33 3 - Bienal de Veneza, na Itália, em 1966. Outro grande destaque foi o carioca Heitor dos Prazeres (1898-1966) que participou da primeira Bienal Internacional de São Paulo, onde venceu um dos prêmios (ARDIES, 1998). A mais tradicional e importante exposição de arte naif brasileira é a Bienal Naifs do Brasil, realizada pelo Serviço Social do Comércio - SESC de Piracicaba, selecionando os participantes por meio de edital, sendo a seleção mais disputada do Brasil. A demanda é grande por eventos de arte naif, o que impulsionou a criação de mais eventos recentemente, como: a Bienal Internacional de Arte Naif Totem Cor-Ação - BINAIF de Socorro/SP; a Mostra Nacional de Arte Naif no Estado de São Paulo; o Festival Internacional de Arte Naif - FIAN de Guarabira/PB; a Mostra Naif Pequenos Formatos de Paraty/RJ; a Exposição Nacional de Artistas Naifs do Centro-Oeste - ENANCO de Goiânia/GO; e a Mostra Internacional da Arte Naif "Universo da Alma Ingênua" de Santa Teresa/ES. Portanto, no Brasil a arte naif está em expansão, a cada ano cresce o número de artistas e a demanda faz surgir mais ofertas de eventos, além do interesse de colecionadores e de galerias.

\subsection{OS RECURSOS HÍDRICOS BRASILEIROS}

O Brasil possui aproximadamente $12 \%$ das águas doces disponíveis no mundo inteiro, mas a disponibilidade hídrica pelo território brasileiro é irregular, em alguns locais existe água em abundância e em outros existe a escassez de água (ANA, 2012). No Brasil, três bacias hidrográficas têm um papel relevante do ponto de vista de disponibilidade de recursos hídricos, reserva estratégica de águas e de economia regional e nacional: a Bacia Amazônica; a Bacia do Rio da Prata; e a Bacia do Rio São Francisco (TUNDISI, 2014). No que tange as águas oceânicas, segundo o Atlas 
lançado pela Fundação SOS Mata Atlântica e pelo Instituto Nacional de Pesquisas Espaciais - INPE (2018), a Zona Costeira do Brasil é uma unidade territorial que se estende na sua porção terrestre por mais de $10.800 \mathrm{~km}$, sendo banhada pelo Oceano Atlântico. Dessa forma, o Brasil é o segundo maior país em extensão litorânea da América Latina. Diante de tanta riqueza hídrica, em 1997, foi aprovada no Brasil a Lei 9.433, conhecida como Lei das Águas, que instituiu a Política Nacional de Recursos Hídricos. Uma de suas diretrizes é garantir os usos múltiplos das águas, de maneira que todos os setores usuários tenham igualdade de acesso aos recursos hídricos. São exemplos de usos múltiplos das águas: abastecimento público, agropecuária, indústria, geração de energia, navegação, pesca, turismo, recreação, entre outros. A exceção dessa regra está relacionada a situações de escassez, quando o uso prioritário da água passa a ser o consumo humano e a dessedentação de animais (Lei 9433/1997, Art 1ํㅡㄴ III e IV).

\section{MATERIAL E MÉTODOS}

Este estudo analisou recursos hídricos do Brasil pintados por artistas naifs brasileiros. Pesquisa documental, baseada nos catálogos das seguintes exposições: Bienal Naifs do Brasil do SESC de Piracicaba/SP (1996 a 2018); Bienal Internacional de Arte Naif Totem Cor-Ação - BINAIF de Socorro/SP (2017 e 2019) e a Mostra Nacional de Arte Naif no Estado de São Paulo (2019). No total, são 15 catálogos, sendo os catálogos das Bienais impressos e o da Mostra Nacional virtual, com aproximadamente 2.400 obras e cerca de 1.200 artistas. Foram selecionadas 15 obras, nas quais foram abordados aspectos relacionados: a Bacia Amazônica; a Bacia do São Francisco; a Bacia do Prata; o litoral brasileiro banhado pelo Oceano Atlântico; a escassez de recursos hídricos; a poluição dos recursos hídricos; as inundações; e usos múltiplos das águas (consumo humano e de animais, pesca, navegação, agropecuária, turismo e recreação). Nas obras selecionadas também foram observadas questões geográficas, históricas, culturais, além dos diferentes biomas. O estudo foi descritivo, com análise qualitativa das pinturas e suas relações com os recursos hídricos brasileiros. Por sua vez, os recursos hídricos pintados nas obras foram apresentados de forma técnica. 


\section{RESULTADOS E DISCUSSÃO}

Analisando a pintura, Figura 1, pode-se localizar geograficamente a cena na Região Norte do país. O artista fez uma homenagem ao Estado do Pará. Pode-se observar no primeiro plano as pessoas dançando carimbó (dança típica), ao fundo um prédio histórico de Belém, o mercado Ver-o-Peso. A cidade é banhada pelo rio Guamá e pela Baía do Guajará, ambos de coloração barrenta e pertencentes a Bacia Amazônica.

Figura 1: As águas barrentas que banham Belém/PA.

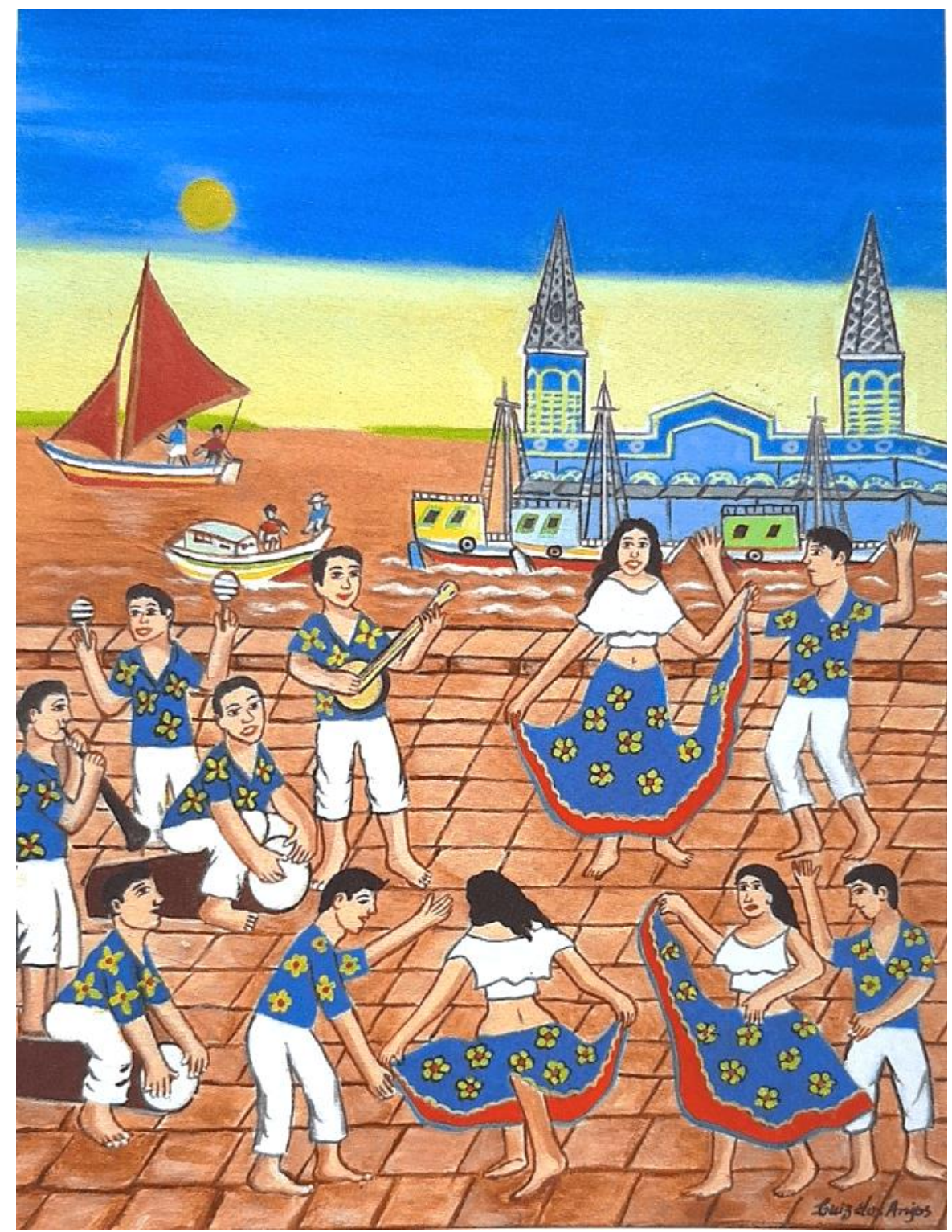

Fonte: Catálogo da Bienal Naifs do Brasil, 2012, p. 141. Carimbó, Luiz dos Anjos.

Disponível em: https://www.nucleodoconhecimento.com.br/arte/arte-e-meio-ambiente 
A Bacia Amazônica é a maior bacia hidrográfica do mundo em extensão e volume de água, sua área tem cerca de 7 milhões de $\mathrm{km}^{2}$, e a vazão do rio Amazonas, em torno de 220.000 m³/s (TUNDISI, 2014). A Bacia Amazônica ocupa, no Brasil, uma área de aproximadamente 4 milhões de $\mathrm{km}^{2}$, o que equivale a cerca de $45 \%$ do território nacional (ANA, 2012).

Analisando a Figura 2, observa-se o encontro das águas pretas do rio Negro com as águas amarela-barrentas do rio Solimões, próximo a Manaus/AM. Nota-se ainda, um barco típico da região. Os rios são os principais meios de acesso na região, funcionam como hidrovias, levando e trazendo pessoas e mercadorias. Os rios foram dispostos em dois triângulos retângulos. A paleta de cores ressaltou o encontros dos rios.

Figura 2: O encontro das águas do rio Negro com as águas do rio Solimões.

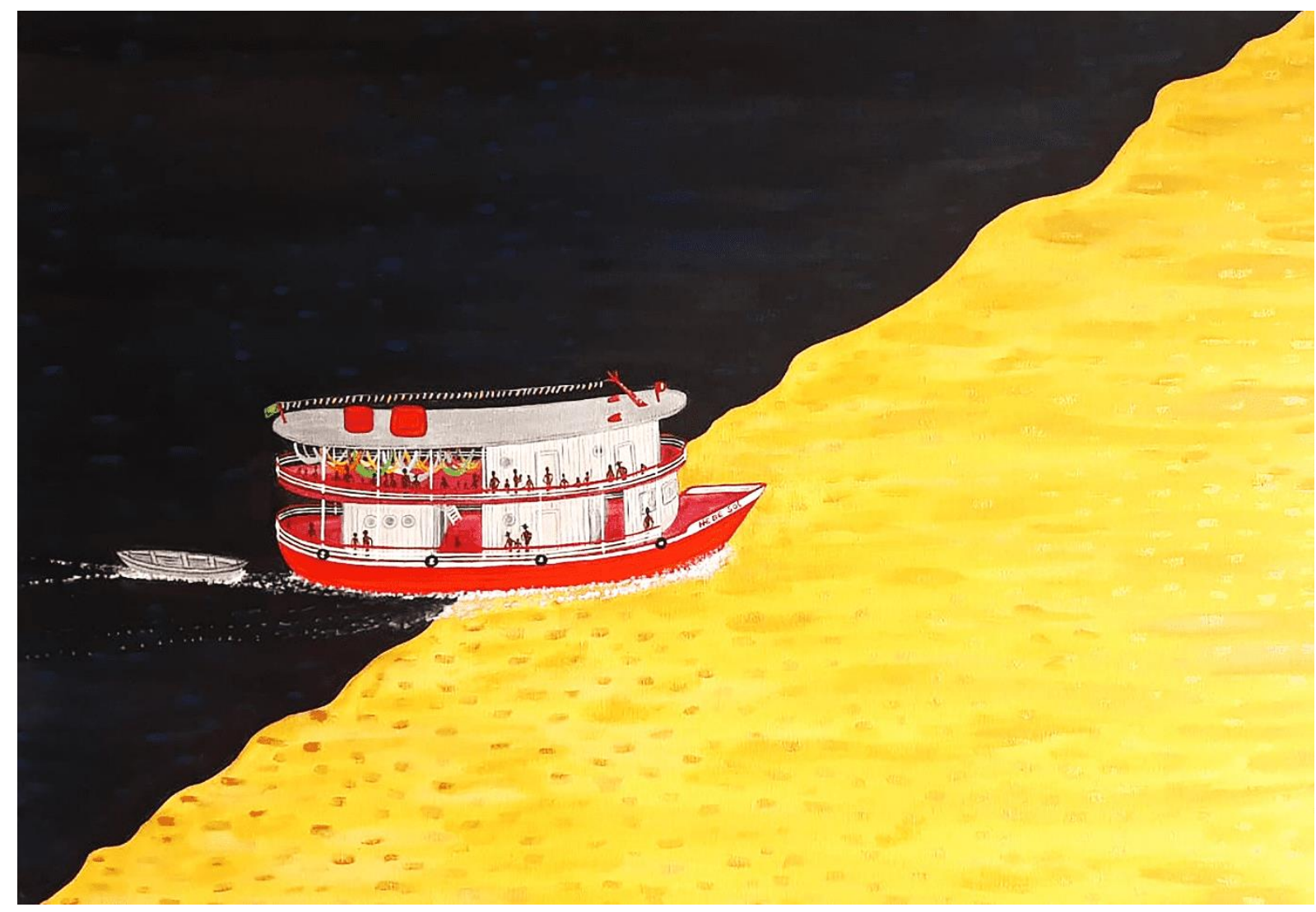

Fonte: Catálogo Virtual da Mostra Nacional de Arte Naif no Estado de São Paulo, 2019. Entre o Rio Negro e o Solimões, Hebe Sol. Disponível em: <https://enzoferrara75.wixsite.com/olhosnaifs/encontro-nacional-de-arte-naif-2019> 
O rio Solimões (águas brancas) e o rio Negro (águas pretas) pertencem a Bacia Hidrográfica Amazônica. Os rios de águas barrentas (águas brancas) possuem alta turbidez, são ricos em nutrientes, íons dissolvidos e sedimentos, além disso, tem pH mais básico. Essas características são devido a erosão e, entre outros fatores, à forte declividade nas cabeceiras desses rios localizadas na porção andina. Os rios de águas pretas apresentam uma coloração escura devido à presença de substâncias orgânicas dissolvidas, possuem $\mathrm{pH}$ ácido, baixa carga de sedimentos e baixa concentração de cálcio e magnésio. As propriedades químicas dessas águas pretas são determinadas pelos solos arenosos e pela campinarana (vegetação) característica que ocorre nas nascentes dos rios (ANA, 2012). O encontro da águas do rio Solimões (águas amarela-barrentas) e o rio Negro (água pretas) é um dos pontos turísticos de Manaus, capital do Amazonas. Os dois rios não se misturam por quilômetros, os motivos envolvem questões geológicas, além de diferentes velocidades, volume, densidades, temperaturas e acidez. Após a mistura da águas do rio Negro e Solimões, o rio passa a se chamar rio Amazonas (FRANZINELLI, 2011).

Analisando a Figura 3, observa-se um grupo de lavadeiras, um ofício que é uma tradição do Velho Chico (rio São Francisco). Na imagem também pode ser observado crianças brincando no rio, canoas e pessoas pescando. A pintura faz uma referência cultural ligada ao rio, mas geograficamente é um lugar fictício. As cores usadas são saturadas e a pintura é alegre. 
Figura 3: Lavando roupa nas águas do Velho Chico.

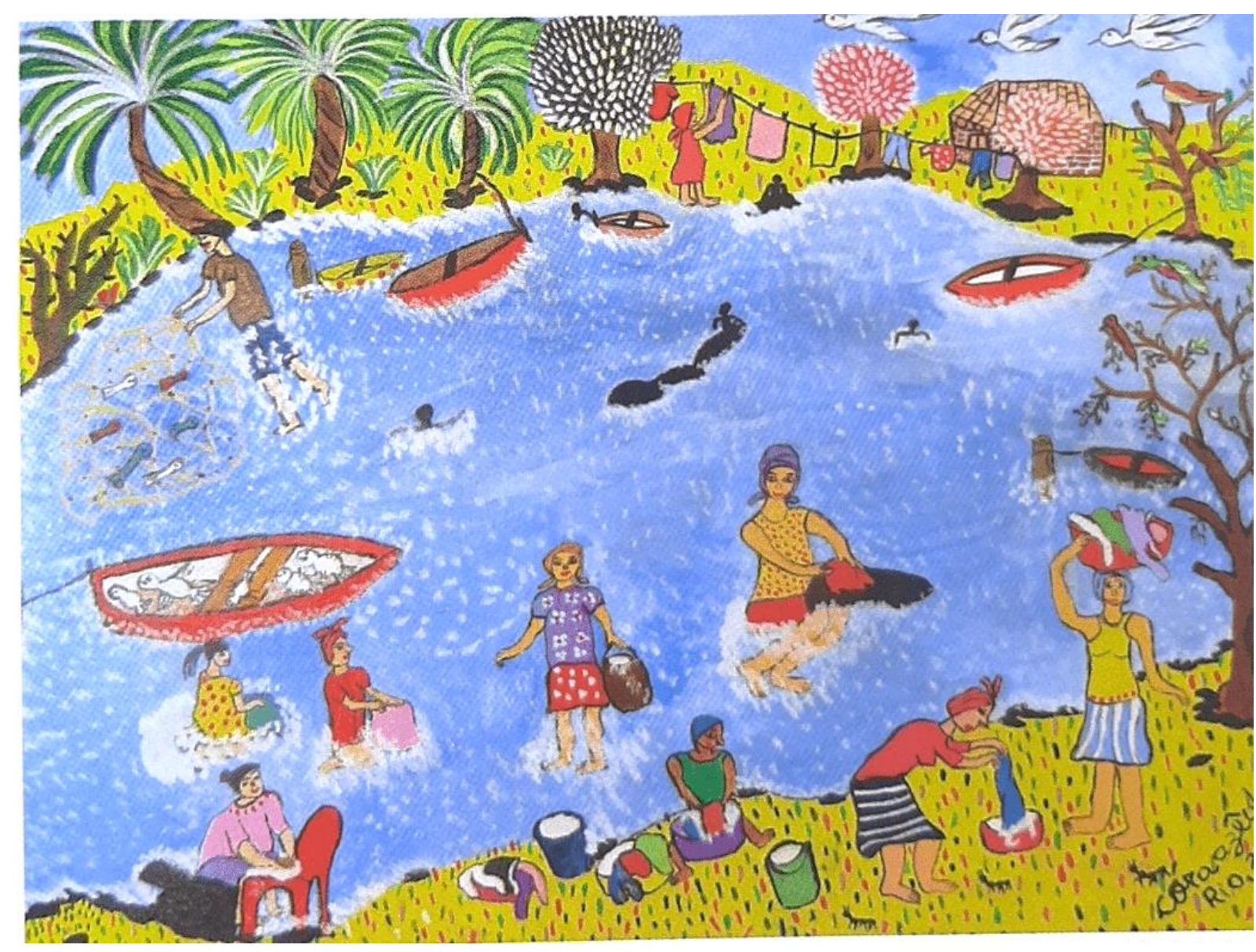

Fonte: Catálogo da Bienal Internacional de Arte Naif - BINAIF, 2019, p. 37. As Lavadeiras do Rio São Francisco, Cora Azêdo.

A área de drenagem do Bacia do São Francisco abrange diversos biomas, como a Mata Atlântica, o Cerrado e a Caatinga. O rio São Francisco nasce na serra da Canastra no município de São Roque de Minas no Estado de Minas Gerais, corta os estados da Bahia e Pernambuco e faz divisa entre os Estados de Sergipe e Alagoas. O rio São Francisco é o mais importante da Região Nordeste, percorre um total de $2.796 \mathrm{~km}$ até desaguar no Oceano Atlântico (ANA, 2012).

Na Figura 4, o local foi geograficamente localizado pelo nome da obra "Nordeste" e pelo aspecto de região do semiárido. Pode-se observar o solo tão seco pela falta de chuva que está todo rachado. As árvores ressecadas, só os cactos devem ainda ter reserva de água. Pelo chão, ossos de animais mortos. As pessoas devem estar 
famintas, estão ansiosas para pegar suprimentos que chegaram no avião aterrissado no local. O lagarto é bichinho de estimação da mulher próxima a uma bandeira, talvez de Padre Cícero (venerado como santo no nordeste). Pode-se ver ainda, uma mulher com um jarro na cabeça, provavelmente para colocar a preciosa água. A pintura tem um aspecto sombrio, que remete a tristeza relacionada a seca na Região Nordeste.

Figura 4: A escassez de água.

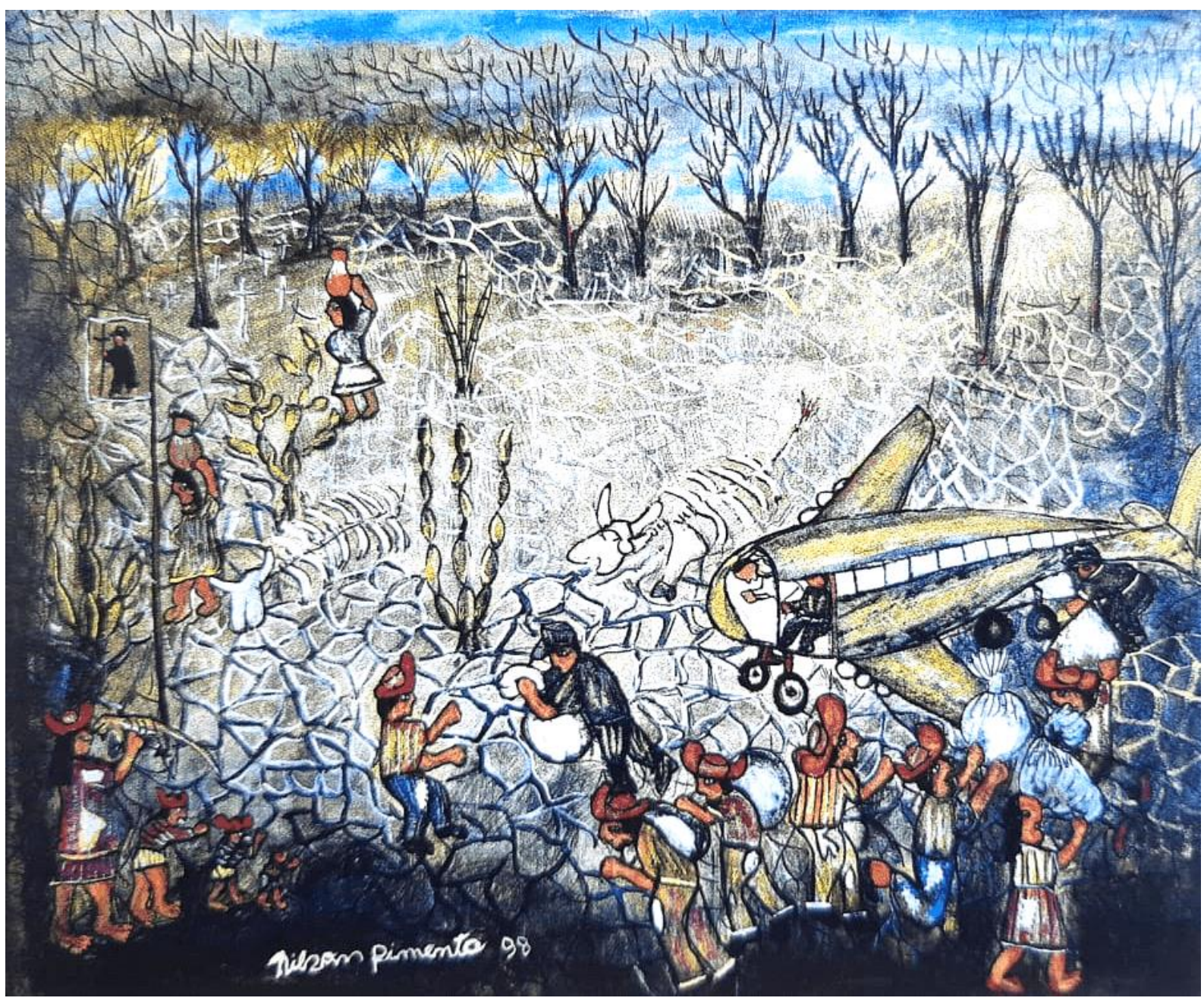

Fonte: Catálogo da Bienal Naifs do Brasil, 2000, p. 111. Nordeste, Nilson Pimenta.

O clima dessa região do semiárido tem precipitações médias anuais de 250 a $500 \mathrm{~mm}$ e tem vegetação adaptada à escassez de água, como a caatinga (TUNDISI, 2014). A estiagem é "o período prolongado de baixa ou ausência de pluviosidade. Caso ocorra por um período de tempo muito longo e afete de forma generalizada os usuários da 
água da região, constitui-se uma seca" (ANA, 2013, p. 9). Episódios de secas na Região Nordeste são relatados desde o século $\mathrm{XVI}$, sendo recorrentes na região. Entretanto, não atinge todo o Nordeste, a seca se concentra numa área conhecida como Polígono das Secas, que envolve as regiões semiáridas de parte de oito estados nordestinos: Alagoas, Bahia, Ceará, Paraíba, Pernambuco, Piauí, Rio Grande do Norte e Sergipe. Além, disso também abrange parte do norte de Minas Gerais (MARENGO; CUNHA; ALVES, 2016). Em regiões em que há falta de água, há níveis baixos de suprimentos em relação ao mínimo indispensável às necessidades básicas de vida. A escassez de recursos hídricos gera instabilidade agropecuária, de abastecimento de água potável, de saneamento básico e de saúde pública. Isso se reflete na intensificação do desequilíbrio social (TUNDISI, 2014).

Analisando a Figura 5, pode-se observar uma prática de aventura de rafting no rio do Peixe. Essa prática de recreação atrai turistas para o interior do Estado de São Paulo, contribuindo para o desenvolvimento econômico das cidades paulistas, a exemplo da cidade de Socorro onde também é realizada a BINAIF.

Figura 5: Águas para recreação e turismo

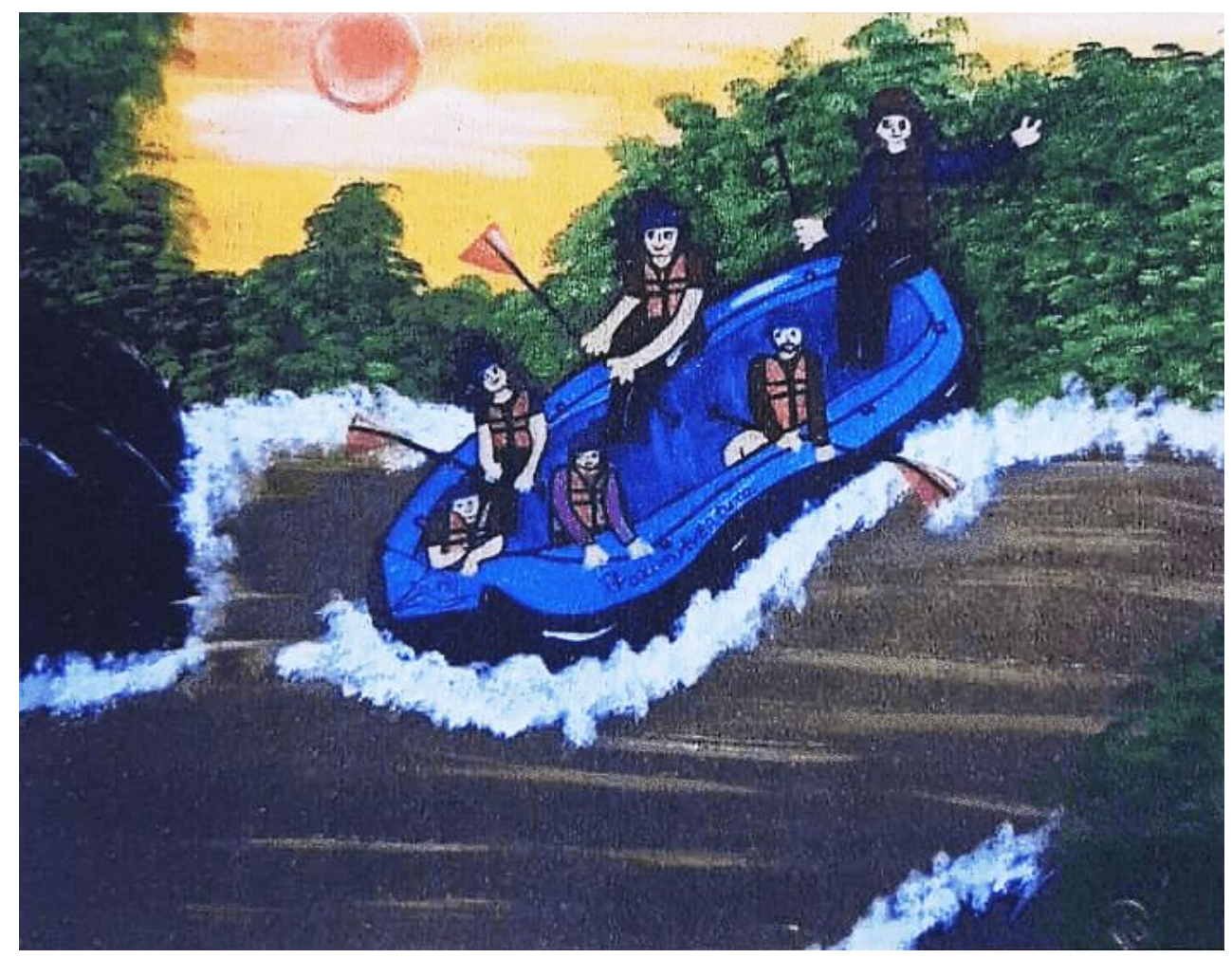

RC: 52974

Disponível em: https://www.nucleodoconhecimento.com.br/arte/arte-e-meio-ambiente 
Fonte: Catálogo da Bienal Internacional de Arte Naif - BINAIF, 2017, p. 17. Rafting Rio do Peixe, Andreia Gonçalves.

O rio do Peixe nasce no município de Garça no Estado de São Paulo, o rio corre em direção ao oeste do estado e desemboca no rio Paraná (SIGRH, 2020). Por sua vez, o rio Paraná com 4.880 km de extensão é o principal formador da Bacia do Prata, a segunda maior bacia do Brasil, e onde se concentram a maior parte da produção de energia elétrica no país (ITAIPU, 2020).

Analisando a Figura 6, observa-se no primeiro plano, pescadores um barco com o nome de rio Pantanal, geograficamente localizando onde ocorre a ação pintada. Podese observar também, as pequenas ondulações das águas de coloração esverdeada. Ao fundo, observa-se uma ave típica, o Tuiuiú (Jabiru mycteria), próximo a vegetação, que representa as gramíneas das planícies inundadas.

Figura 6: Pescando em um rio do Pantanal

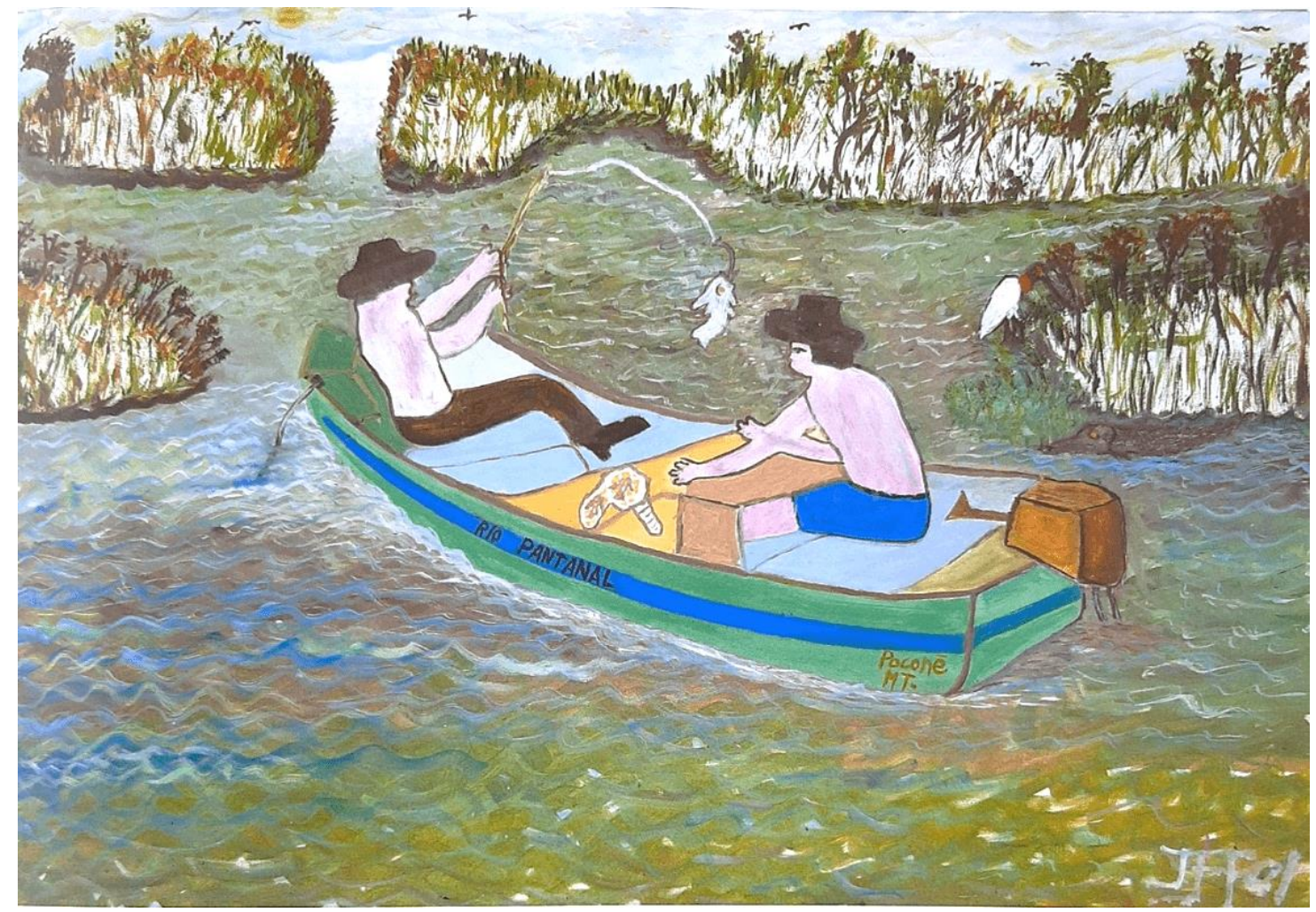

Fonte: Catálogo da Bienal Naifs do Brasil, 2012, p. 131. Barco do pescador, Jefer. 
O Pantanal é considerado uma das maiores extensões úmidas contínuas do planeta. A sua área aproximada corresponde a cerca de $1,76 \%$ do território brasileiro, ocupando parte dos Estados de Mato Grosso e Mato Grosso do Sul, na Região Centro-Oeste. O bioma, que é uma planície aluvial - formações geológicas que se caracterizam por serem planas ou muito pouco inclinadas - é influenciado por rios que drenam a bacia hidrográfica do Alto Paraguai (MMA, 2020).

A Figura 7 foi selecionada por mostrar um pouco da biodivesidade dos rios brasileiros. Analisando a pintura, observa-se um indígena agarrado a um peixe, ao mesmo tempo, ele é agarrado por uma cobra.

Figura 7: Biodiversidade dos rios brasileiros.

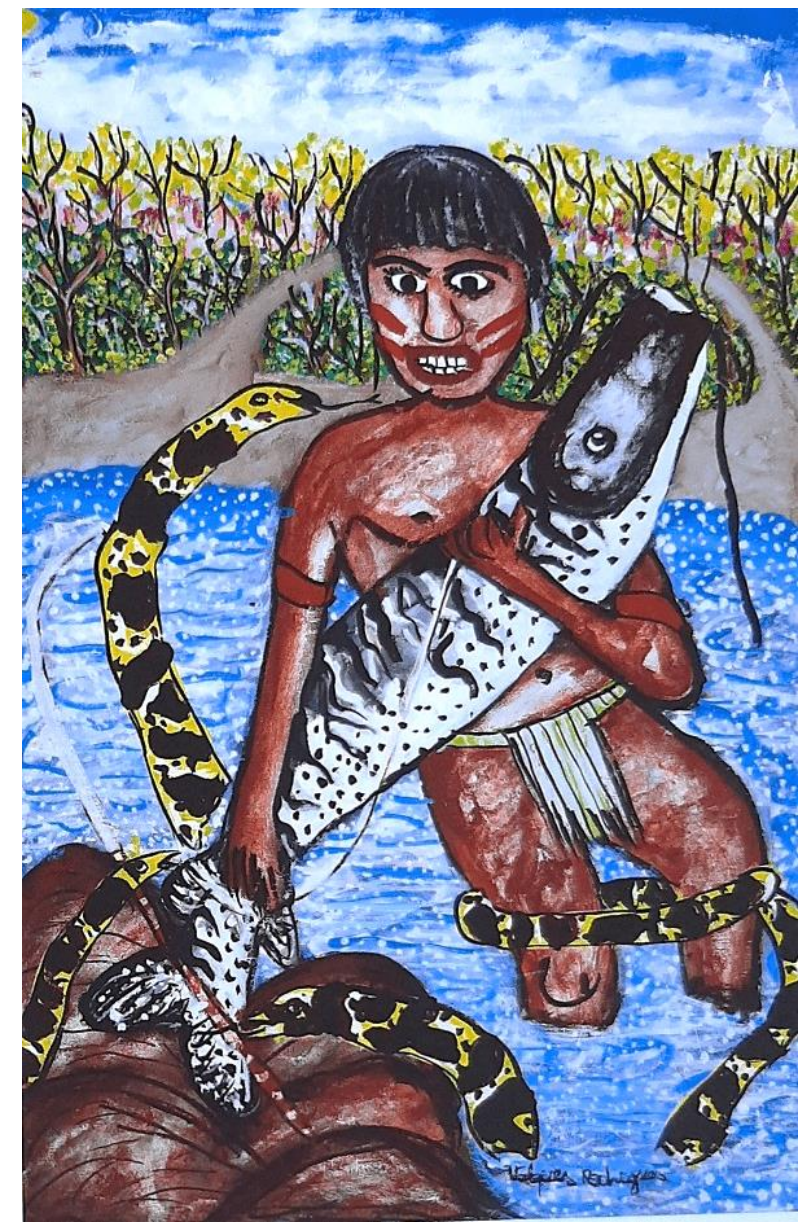

Fonte: Catálogo da Bienal Naifs do Brasil, 2010, p. 139. Predadores II, Valques Rodrigues. 
O peixe é um bagre, um surubim-cachara (Pseudoplatystoma fasciatum) encontrado nas Bacias Hidrográficas: Amazônica, Araguaia-Tocantins e do Prata (AMBIENTE BRASIL, 2020). A cobra lembra uma sucuri-amarela (Eunectes notaeus), espécie que ocorre em áreas que inundam anualmente, influenciadas pelas cheias do Rio Paraguai, nas regiões próximas às fronteiras entre Brasil, Bolívia, Paraguai e Argentina (O ECO, 2020).

Analisando a Figura 8, a praia da pintura é localizada geograficamente pelo nome da obra: Jurerê. A praia fica localizada ao norte da llha de Florianópolis, no Estado de Santa Catarina, Região Sul do Brasil. A obra mostra a praia lotada, com pessoas se divertindo na areia e no mar. Há também vendedores ambulantes, barracas e posto de salva-vidas. A pintura é muito alegre, um cenário de férias.

Figura 8: Oceano Atlântico banhando uma Praia brasileira da Região Sul.

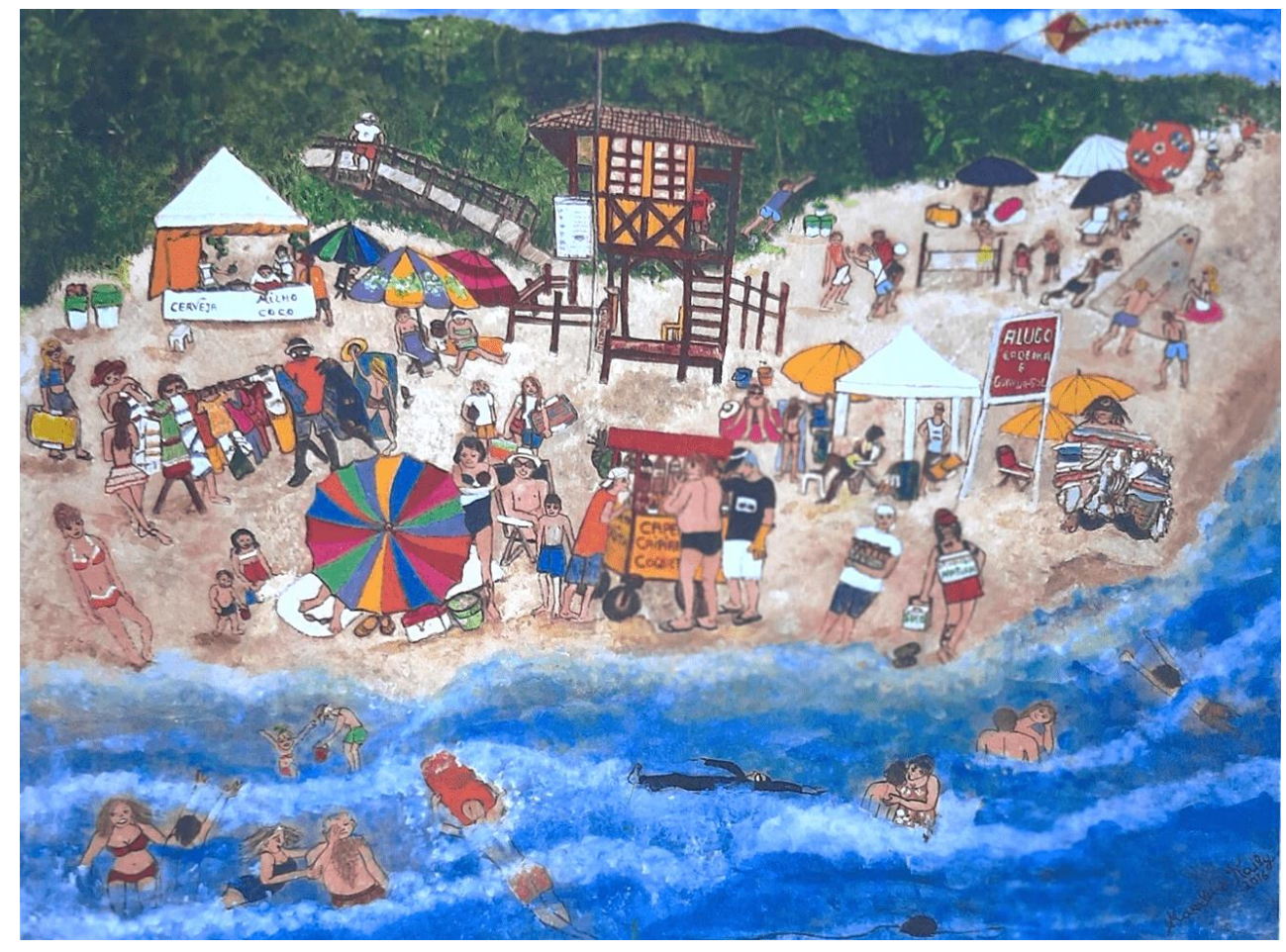

O Brasil tem uma das maiores faixas costeiras do mundo, com belíssimas praias banhadas pelo Oceano Atlântico. Segundo o Atlas lançado pela Fundação SOS Mata Atlântica e pelo Instituto Nacional de Pesquisas Espaciais - INPE (2018), o Brasil 
concentra na região costeira cerca de dois terços da população do país e $75 \%$ dos principais centros urbanos.

Analisando a Figura 9, geograficamente é a Praia de Ipanema e ao fundo parece ser as Ilhas Cagarras. Portanto, o artista pintou uma praia localizada na cidade do Rio de Janeiro, capital do estado com o mesmo nome, na Região Sudeste. Na praia, há pessoas e barracas. O mar está cheio de barquinhos. O conceito da obra é uma crítica: as sombras projetadas na faixa de areia pelos prédios próximos a praia. A paisagem sugere que seja um clima quente. $O$ artista usou uma paleta de cores saturadas. $A$ distribuição espacial da pintura é bem interessante, já que o artista dividiu a tela em 3 faixas horizontais: uma para a areia de cor amarela-barrenta; outra para o mar de cor azul cobalto; e outra para o céu em tom de azul mais claro. As duas faixas azuis, uma mais escura que a outra, causam uma impressão de degradê. A pintura tem um aspecto de elaboração racional e minuciosa.

Figura 9: Oceano Atlântico banhando uma Praia brasileira da Região Sudeste.

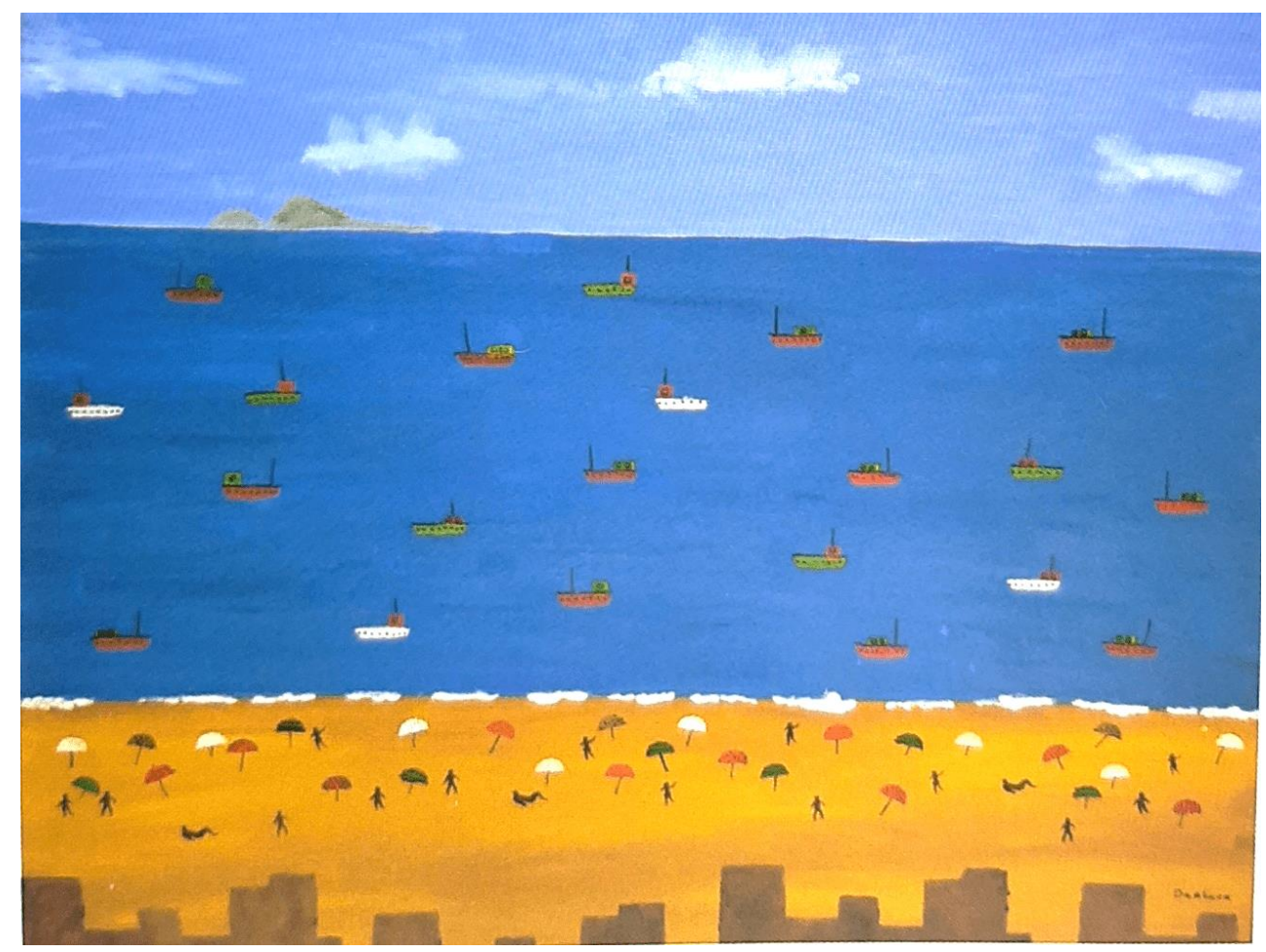

Fonte: Catálogo da Bienal Internacional de Arte Naif - BINAIF, 2019, p. 38. Praia de Ipanema com areias sem sombra, Danbeco. 
Analisando a figura 10, geograficamente, ao fundo é o Farol do Cabo Branco que fica sobre uma falésia na Praia de Cabo Branco, em João Pessoa, capital da Paraíba. Observa-se também, uma banda tocando, uma ciranda, as pessoas estão vestidas com roupas coloridas, típico da cultura da região. No mar há uma canoa enfeitada. A paleta de cores é saturada. A pintura sugere um clima quente.

Figura 10: Oceano Atlântico banhando uma praia brasileira da Região Nordeste.

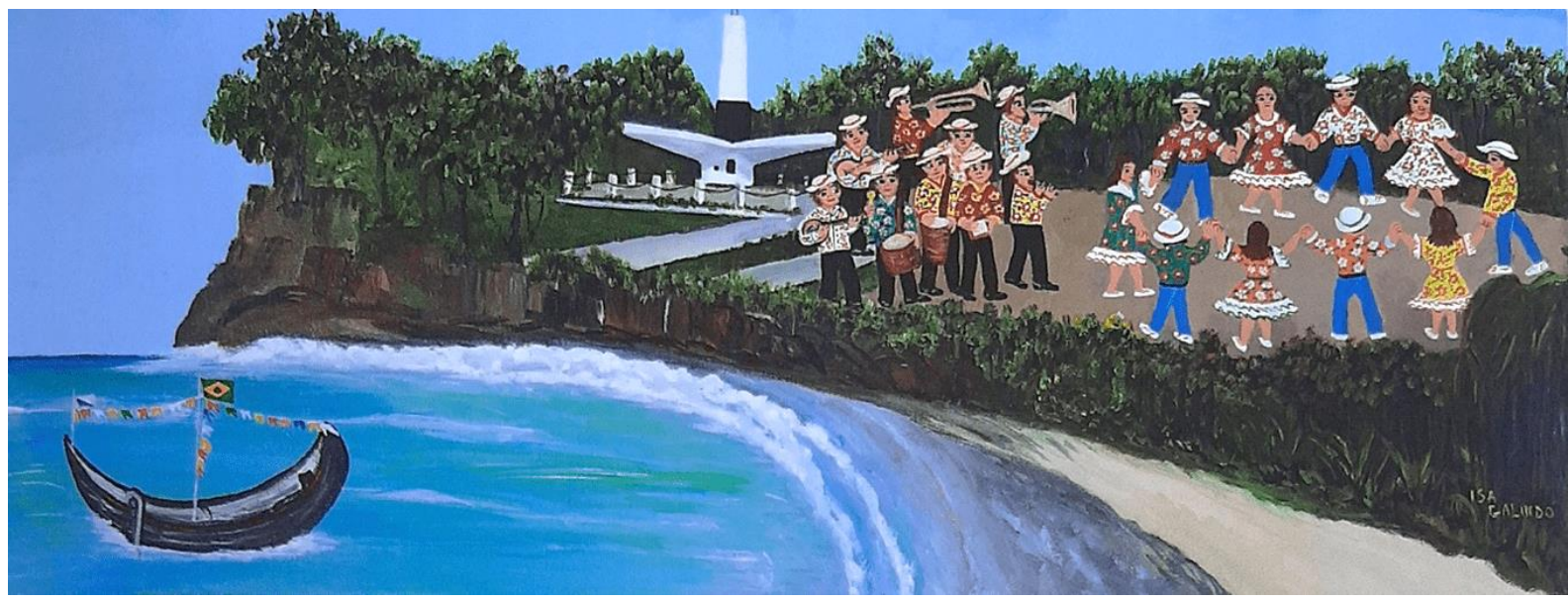

Fonte: Catálogo da Bienal Naifs do Brasil, 2010, p. 121. Ciranda da Praia do Cabo Branco, Isa Galindo.

Analisando a Figura 11, observa-se um cenário fictício, com uma lago ou curso d'água poluído por resíduos sólidos. Esta pintura foi escolhida porque mostra a degradação do meio ambiente por objetos descartados de maneira indevida. A pintura é interessante porque serve de alerta para um problema real que ocorre no Brasil. 


\section{MULTIDISCIPLINARY SCIENTIFIC JOURNAL

Figura 11: A poluição dos recursos hídricos.

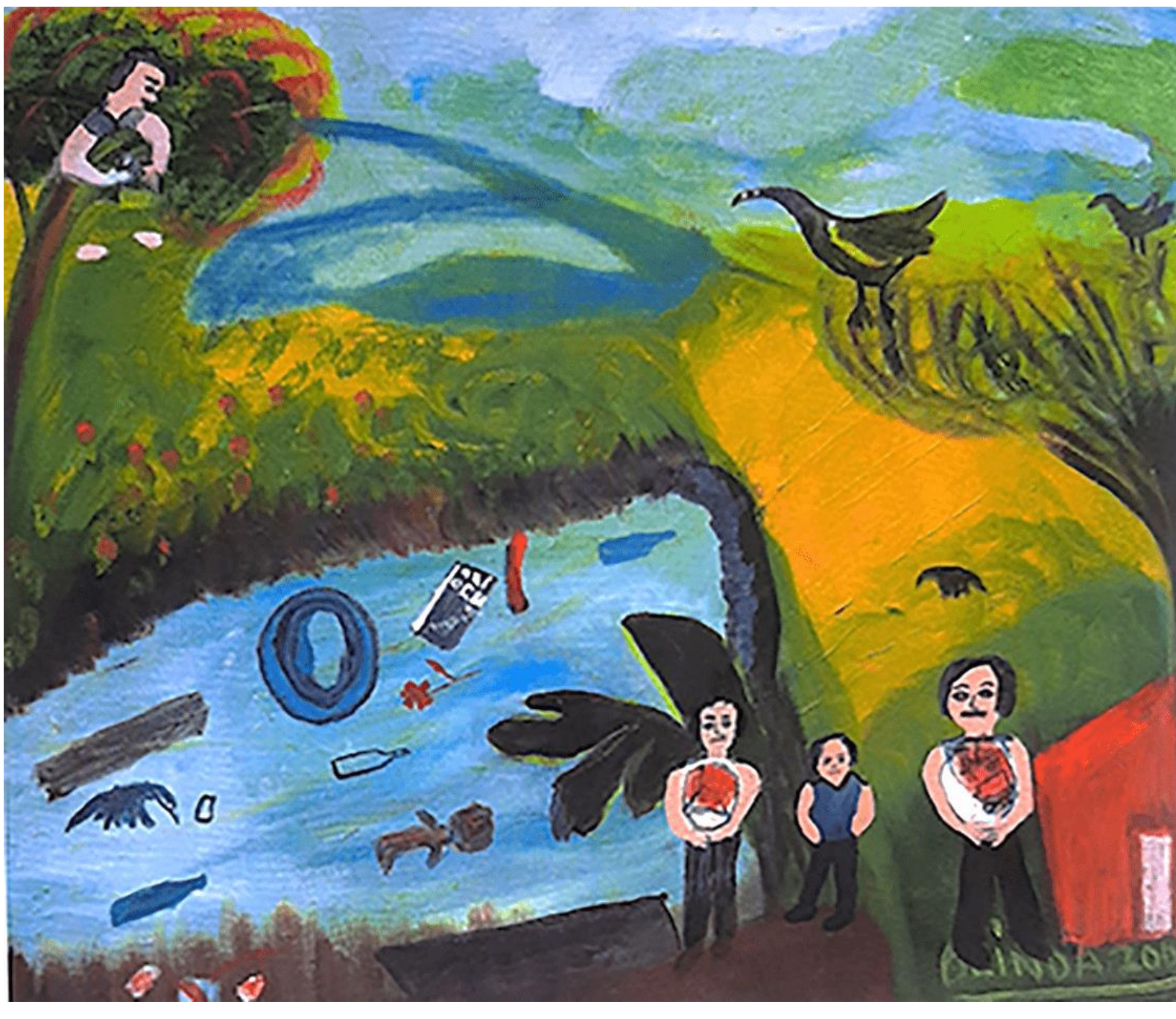

Fonte: Catálogo da Bienal Naifs do Brasil, 2006, p. 126. A Destruição da Natureza, Olinda da Silva.

Segundo o Panorama dos Resíduos Sólidos 2018/2019, produzido pela Associação Brasileira das Empresas de Limpeza Pública (ABRELPE), em 2018 o Brasil gerou 79 milhões de toneladas de resíduos sólidos. Deste montante, cerca de $40 \%$ dos resíduos coletados recebeu destinação inadequada. Dessa forma, muitos resíduos sólidos descartados indevidamente acabam poluindo o meio ambiente, inclusive os recursos hídricos.

Analisando a Figura 12, observa-se um cenário de inundação causada por fortes chuvas. Geograficamente, o local é a Vila Pantanal, como sugere o nome do prédio 
do S.U.S, de cor verde. As casas estão sendo alagadas e as águas já encobriram um automóvel. Algumas pessoas estão sendo resgatadas por helicóptero, outras de barco. Enquanto isso, animais e pessoas se refugiam nos telhados, aguardando resgate. Mas, ainda existem pessoas dentro das casas preocupadas com a subida das águas. A cor escura das águas pode ser relacionada a presença de efluentes.

Figura 12: A enchente na Vila Pantanal.

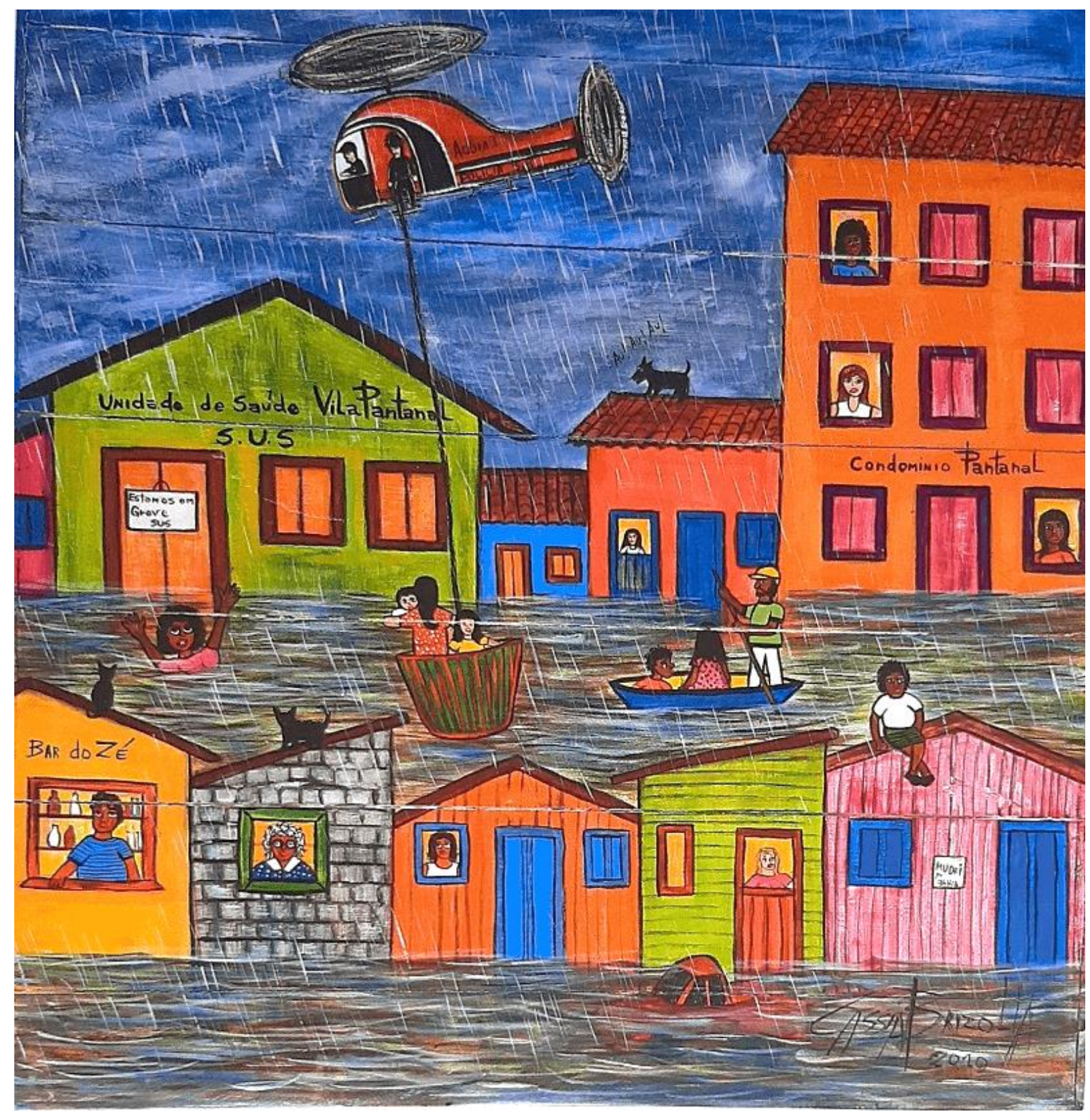

Fonte: Catálogo da Bienal Naifs do Brasil 2010, p. 68. O Haiti é Aqui, Cássia Brizolla. 
As inundações são o "transbordamento de água da calha normal de rios, mares, lagos e açudes, ou acumulação de água por drenagem deficiente, em áreas não habitualmente submersas" (ANA, 2013, p. 9). Na pintura, Figura 12, o artista sugere ser a Vila Pantanal. Em Curitiba, capital do Estado do Paraná, existe um local chamado de Vila Pantanal, onde há registros de ocorrência de enchentes. No Brasil, há vários locais considerados áreas de risco de enchentes.

Analisando a Figura 13, observa-se um dia de chuva em uma cidade, as pessoas utilizando guarda-chuvas enquanto caminham normalmente. Nesta pintura, a chuva é bem-vinda.

Figura 13: Um dia de chuva comum na cidade.

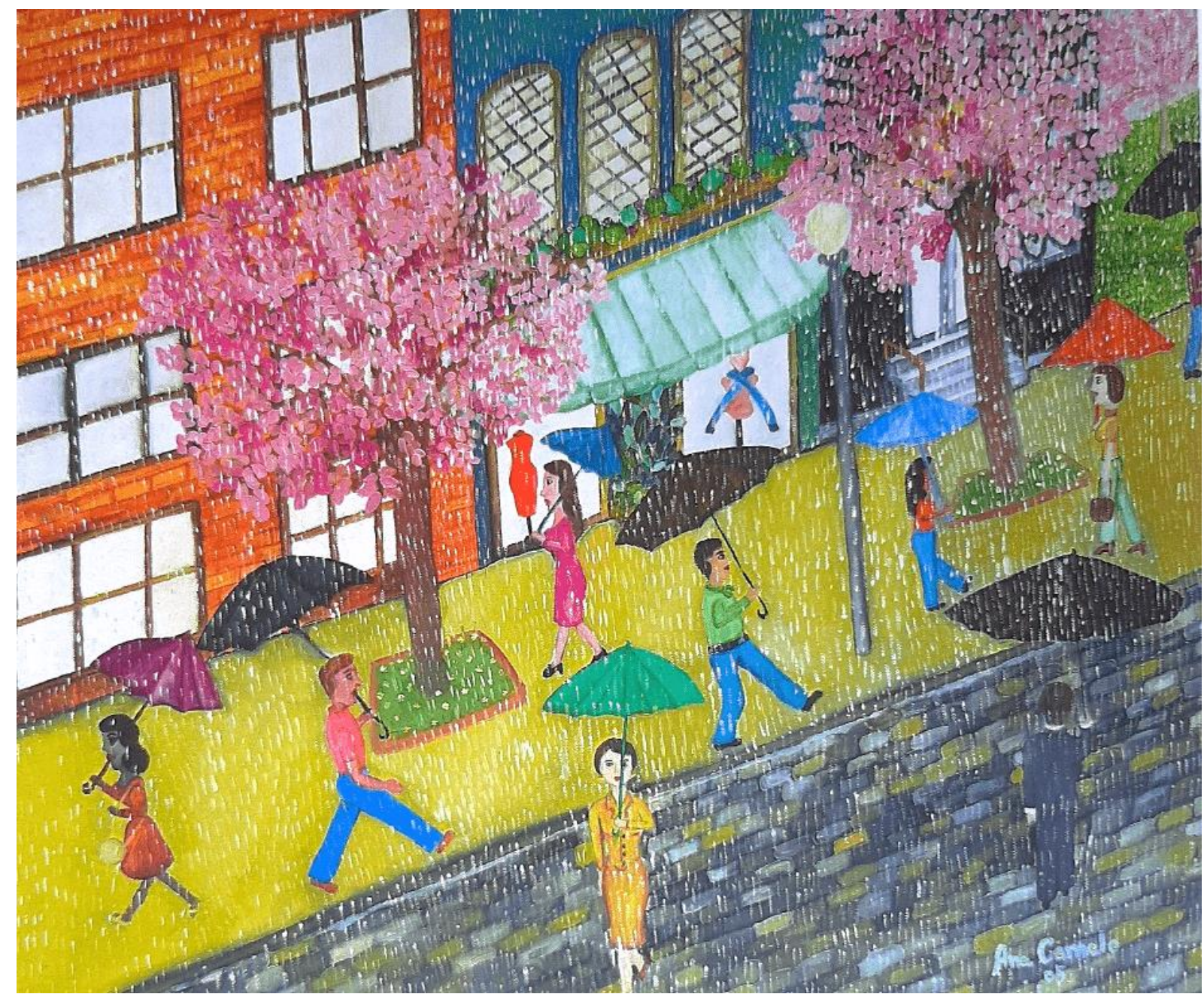

Fonte: Catálogo da Bienal Naifs do Brasil, 2006, p. 66. Dia de Chuva, Ana Camelo. 
A Figura 14 não representa um lugar real por isso não é possível localizar geograficamente. Entretanto, ela foi escolhida porque mostra usos múltiplos da água. Pode-se observar um rio onde há uma canoa e barquinhos, representando o uso na navegação. No mesmo rio, pessoas pescam para consumo próprio, como atividade econômica ou até mesmo como forma de recreação. Os peixes também representam a biodiversidade do rio. Pode-se observar pessoas nas águas, que podem estar nadando, brincando ou simplesmente tomando banho. A água parece limpa e própria para o consumo humano e também dos animais. Há um pequeno pasto para o gado, plantações agrícolas, criações de vários animais, mas também existe uma vegetação próxima ao rio. As pessoas trabalham e se divertem ao redor do rio. São os recursos hídricos que possibilitam uma paisagem rural bonita e feliz.

Figura 14: Usos múltiplos das águas.

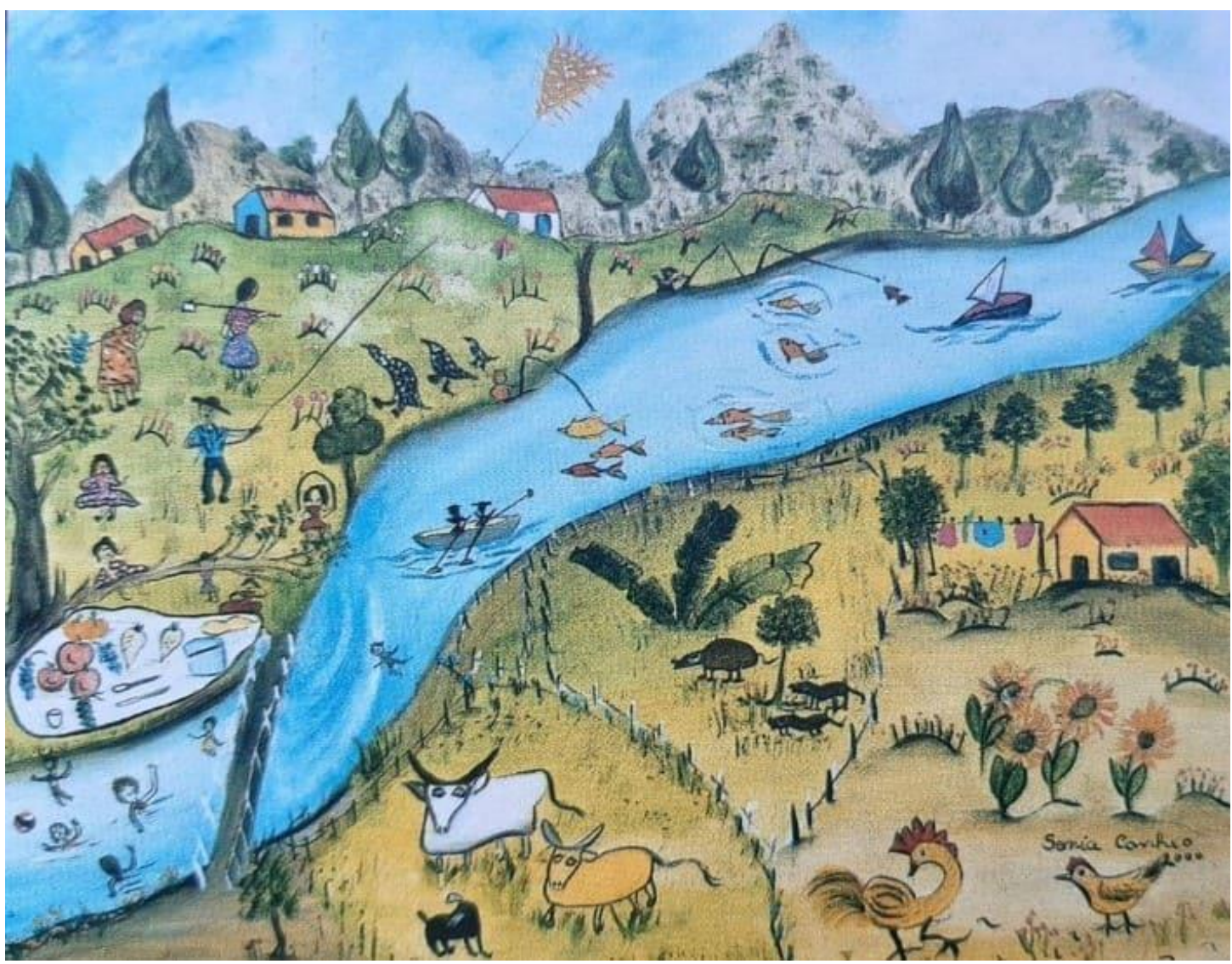

Fonte: Catálogo da Bienal Naifs do Brasil, 2000, p. 130. O PIC-NIC, Sonia Maria B. Canheo. 
No catálogo da Bienal Naifs do Brasil do SESC de Piracicaba/SP, realizada no ano de 2012, cada artista selecionado preencheu uma ficha com informações pessoais e respondeu algumas perguntas. Nessa ficha também havia um espaço para o artista fazer um desenho ou escrever uma mensagem. Depois, essas fichas fizeram parte do catálogo dessa edição da Bienal, como uma espécie de apresentação de cada artista. Uma dessas fichas foi a do senhor Nivaldo Rosa, o desenho dele na ficha é a Figura 15. O artista deu a obra o título de "Sede de Vida". Muitas coisas poderiam ser ditas sobre essa pintura por ser tão reflexiva e profunda. Mas, a sua essência se traduz assim: água é vida.

Figura 15: Água é vida.

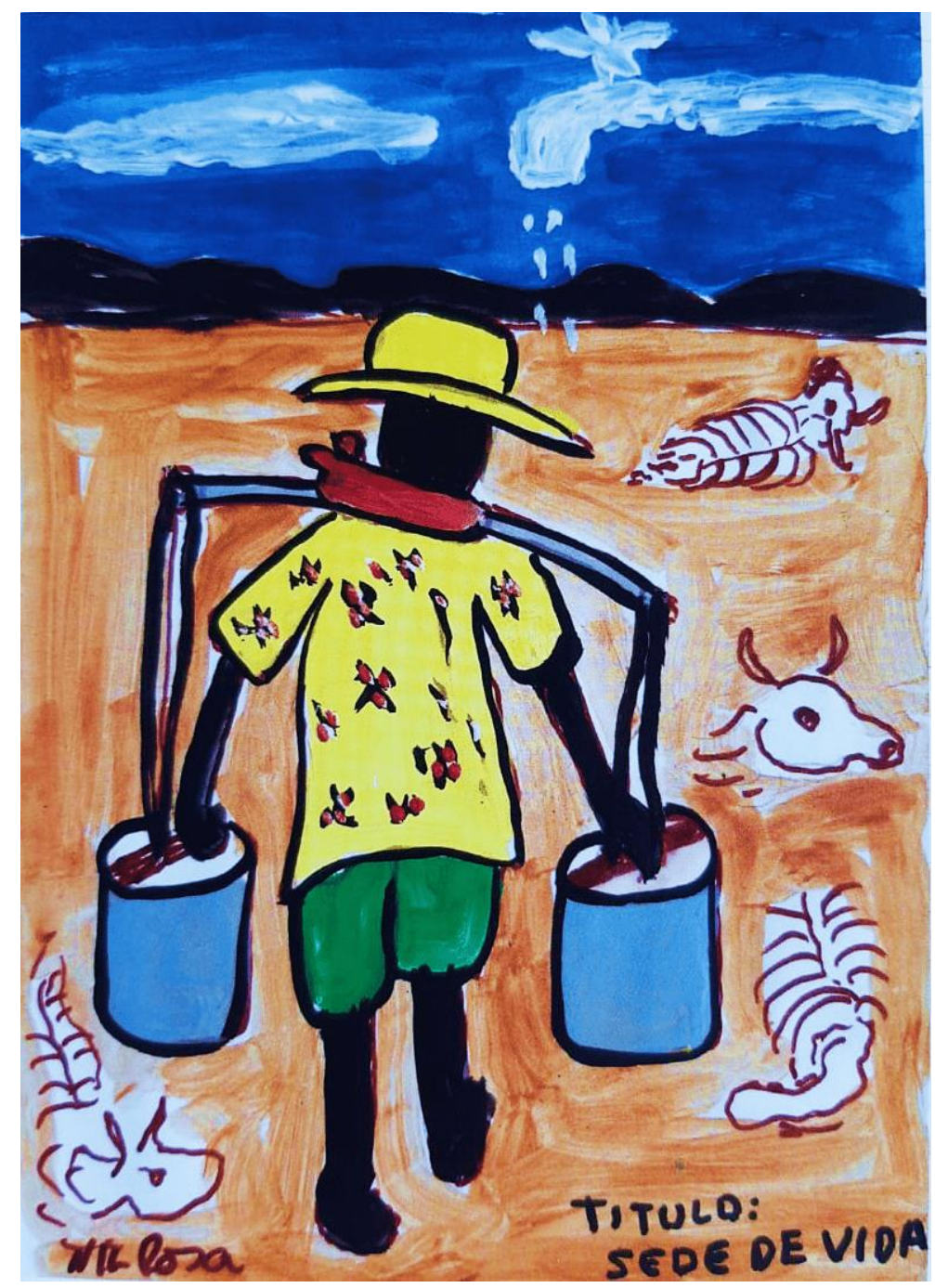

Fonte: Catálogo da Bienal Naifs do Brasil, 2012, p. 45. Sede de vida, Nivaldo Rosa. 


\section{CONSIDERAÇÕES FINAIS}

Esta pesquisa analisou 23 anos de arte naif no Brasil por meio de catálogos de importantes exposições realizadas no país. Foram selecionadas 15 obras que mostram aspectos interessantes dos recursos hídricos brasileiros. Ressalta-se que todas as obras analisadas tem um estilo próprio, mas isso é uma das características da arte naif. Considerando-se os usos múltiplos das águas, os usos recorrentes nas pinturas analisadas são a navegação, a pesca e as atividades recreativas. Mas, é importante destacar que o conjunto das obras contemplou todas as regiões do país, abrangendo as águas continentais superficiais e as oceânicas que banham o litoral brasileiro. O conjunto das obras abordou ainda, problemas como a escassez e a poluição dos recursos hídricos, além de evidenciar como a água é imprescindível para a manutenção da vida. Este trabalho aliou artes e ciências. "Pertencentes a campos distintos, com características peculiares que as singularizam, a Ciência (campo científico) e a Arte (campo artístico) buscam, respectivamente, explicações, representações e interpretações da realidade" (FREITAS; GONÇALVES, 2018, p. 201). Dessa forma, conclui-se que a água é um recurso natural indispensável, valorizá-la por meio da arte naif também incentiva a sua preservação e dessa maneira contribui com a gestão dos recursos hídricos.

\section{AGRADECIMENTOS}

Os autores agradecem a Universidade do Estado do Amazonas (UEA), ao Mestrado Profissional em Rede Nacional em Gestão e Regulação de Recursos Hídricos (PROFÁGUA), e ao Serviço Geológico do Brasil (CPRM) pelo apoio recebido. Agradece ainda, ao SESC de Piracicaba, a produção da BINAIF e ao site Olhos Naifs pela utilização dos catálogos nesta pesquisa. Os autores agradecem a todos que estão trabalhando para divulgar a arte naif, especialmente, aos artistas naifs do Brasil.

\section{REFERÊNCIAS}

ABRELPE. Panorama dos Resíduos Sólidos 2018/2019. Disponível em: <http://abrelpe.org.br/download-panorama-2018-2019/> Acesso em: 20/05/2020. 
AGÊNCIA NACIONAL DE ÁGUAS (ANA). Panorama da qualidade das águas superficiais do Brasil: 2012/Agência Nacional de Águas. Brasília: ANA, 2012. Disponível em: $<$ http://arquivos.ana.gov.br/imprensa/publicacoes/Panorama_Qualidade_Aguas_Sup erficiais_BR_2012.pdf> Acesso em: 20/05/2020.

Manual de operação da Sala de Situação da ANA e para apoio aos Estados. Superintendência de Usos Múltiplos e Eventos Críticos. Brasília: ANA, 2013.

AMBIENTE BRASIL. Cachara. Disponível em: $<$ https://ambientes.ambientebrasil.com.br/agua/pesca_esportiva_em_agua_doce/cac hara_-_pseudoplatystoma_fasciatum.html> Acesso em: 20/05/2020.

ARDIES, Jacques; textos de Andrade, Geraldo Edson. Naive Art in Brazil. 1 ed. São Paulo: Empresa da Artes, 1998.

BINAIF. Catálogo da Bienal Internacional de Arte Naif Totem Cor-Ação. Socorro: ITC Instituto Totem Cultural, 2017 a 2019.

BRASIL. Lei o 9.433, de 8 de janeiro de 1997. Institui a Política Nacional de Recursos Hídricos, cria o Sistema Nacional de Gerenciamento de Recursos Hídricos. Brasília, DF, janeiro de 1997. Disponível em: <http://www.planalto.gov.br/ccivil_03/LEIS/L9433.htm> Acesso em 20/05/2020.

Ministério do Meio Ambiente (MMA). Disponível: <https://www.mma.gov.br/biomas/pantanal> Acesso em: 20/05/2020.

D’AMBROSIO, O. A. F. Um Mergulho no Brasil Naif: A Bienal Naifs do Brasil do SESC Piracicaba 1992 a 2010. 202 f. Tese de Doutorado em Educação, Arte e História da cultura. Universidade Presbiteriana Mackenzie, São Paulo, 2013. Disponível: <http://tede.mackenzie.br/jspui/handle/tede/2068> Acesso em: 20/05/2020. 
ENCICLOPÉDIA, Itaú Cultural de Arte e Cultura Brasileiras. São Paulo: Itaú Cultural, 2020. Disponível em: <http://enciclopedia.itaucultural.org.br/termo5357/arte-naif>. Acesso em: 20/05/2020.

FINKELSTEIN, L. Brasil Naif. Arte Naif: Testemunho e patrimônio da humanidade. 1 ed. Rio de Janeiro: Novas Direções, 2001.

FREITAS, N. M. S.; GONÇALVES, T. V. O. Práticas teatrais e o ensino de Ciências: o teatro jornal da abordagem da temática do lixo. Educar em Revista, Curitiba, Brasil, v. $34, \quad$ n. $68, \quad$ p. $199-216, \quad$ mar./abr. 2018. Disponível:<https://www.scielo.br/pdf/er/v34n68/0104-4060-er-34-68-199.pdf> Acesso em: 20/05/2020.

FRANZINELLI, E. Revista Brasileira de Geociências. 41(4): 587-596, dez. 2011. Disponível: <http://www.ppegeo.igc.usp.br/index.php/rbg/article/view/7855/7282> Acesso em: 20/05/2020.

FUNDAÇÃO, SOS Mata Atlântica; INPE, Instituto Nacional de Pesquisas Espaciais. Atlas dos remanescentes florestais da Mata Atlântica. Mapeamento dos sistemas $\begin{array}{llll}\text { costeiros. } & \text { São } & \text { Paulo: }\end{array}$ Disponível:<http://mapas.sosma.org.br/site_media/download/SOSMA_Atlas-daCosta_Final.pdf> Acesso em: 20/05/2020.

ITAIPU, Binacional. Rio Paraná. Disponível: <https://www.itaipu.gov.br/energia/rioparana> Acesso em: 20/05/2020.

MARENGO, J. A.; CUNHA, A. P.; ALVES, L. M. 2016. A seca de 2012-15 no semiárido do Nordeste do Brasil no contexto histórico. Climanálise, 3, (1), 1-6. Disponível em: <http://climanalise.cptec.inpe.br/ rclimanl/revista/pdf/30anos/marengoetal.pdf> Acesso em: 20/05/2020.

O ECO. O dilema de conviver com sucuris. Disponível em: <https://www.oeco.org.br/reportagens/o-dilema-de-conviver-com-sucuris/> Acesso em: 20/05/2020. 
OLHOS NAIFS. Catálogo Virtual da Mostra Nacional de Arte Naif no Estado de São Paulo. Disponível em: <https://enzoferrara75.wixsite.com/olhosnaifs/encontronacional-de-arte-naif-2019> Acesso em: 20/05/2020.

SESC. Catálogo da Bienal Naifs do Brasil. Piracicaba: SESC, de 1996 a 2018.

SIGRH (ESTADO DE SÃO PAULO). Rio do Peixe. Disponível em: <www.sigrh.sp.gov. br/cbhap/apresentacao> Acesso em: 20/05/2020.

TUNDISI, J. G. Recursos hídricos no Brasil: problemas, desafios e estratégias para o futuro. 76 p. Rio de Janeiro: Academia Brasileira de Ciências, 2014. Disponível em $<$ https://www.researchgate.net/publication/299397625_RECURSOS_HIDRICOS_NO _BRASIL_problemas_desafios_e_estrategias_para_o_futuro> Acesso em: 20/05/2020.

Enviado: Junho, 2020.

Aprovado: Junho, 2020. 